\title{
Esophageal squamous cell carcinomas with distinct invasive depth show different gene expression profiles associated with lymph node metastasis
}

\author{
TOMOMITU SATO ${ }^{1}$, NORIO IIZUKA ${ }^{1,2}$, YOSHIHIKO HAMAMOTO ${ }^{3}$, SHIGEFUMI YOSHINO ${ }^{1}$, \\ TOSHIHIRO ABE ${ }^{1}$, SHIGERU TAKEDA ${ }^{1}$, SHUNJI UCHIMURA ${ }^{3}$, TAKANOBU MIYAMOTO ${ }^{3}$, \\ FUMIYOSHI SEI $^{4}$, KENJI HAMADA ${ }^{4}$, HISAFUMI YAMADA-OKABE ${ }^{4}$ and MASAAKI OKA ${ }^{1}$
}

\begin{abstract}
Departments of ${ }^{1}$ Surgery II and ${ }^{2}$ Complimentary Medicine, Yamaguchi University School of Medicine, 1-1-1 MinamiKogushi, Ube, Yamaguchi 755-8505; ${ }^{3}$ Department of Computer Science and System Engineering, Faculty of Engineering, Yamaguchi University, 2-16-1 Tokiwadai, Ube, Yamaguchi 755-8611; ${ }^{4}$ Pharmaceutical Research Department 3, Kamakura Research Laboratories, Chugai Pharmaceutical Co. Ltd., 200 Kajiwara, Kamakura, Kanagawa 247-8530, Japan
\end{abstract}

Received November 22, 2005; Accepted January 9, 2006

\begin{abstract}
We examined the gene expression profiles of esophageal squamous cell carcinomas (ESCCs) with respect to degree of invasive depth and lymph node (LN) involvement in a large cohort. We used high-density oligonucleotide microarrays to examine the expression of 22,115 genes in 54 ESCCs and 11 non-cancerous esophageal tissues. We found that 4,155 genes were biologically significant in both ESCC and non-cancerous esophageal tissue by analysis of Present Call (hybridization quality by Affymetrix) throughout all samples. From these genes, we used a supervised learning method to select genes responsible for the development of ESCC. We found that 999 genes were expressed differentially in $\mathrm{pT} 1 / \mathrm{pN} 0$ tumors vs. non-cancerous esophageal tissue. In the same manner, 48, 66 and 30 genes were expressed differentially in pT1/pN0 tumors vs. pT1/pN1 tumors, pT1/pN0 tumors vs. pT2-4/ pN0 tumors and $\mathrm{pT} 2-4 / \mathrm{pN} 0$ tumors vs. pT2-4/pN1 tumors, respectively. Intriguingly, there were no overlaps between the $48 \mathrm{LN}$ metastasis-related genes of pT1 tumors and the $30 \mathrm{LN}$ metastasis-related genes of pT2-4 tumors, suggesting that ESCCs with distinct invasive depths express different genes linked to LN metastasis. Our present results suggest that the degree of invasive depth must be considered when predicting LN metastasis of ESCC from gene expression profiles.
\end{abstract}

Correspondence to: Dr Masaaki Oka, Department of Surgery II, Yamaguchi University School of Medicine, 1-1-1 Minami-Kogushi, Ube, Yamaguchi 755-8505, Japan

E-mail: 2geka-1@po.cc.yamaguchi-u.ac.jp

Key words: esophageal squamous cell carcinoma, microarray, progression

\section{Introduction}

Esophageal squamous cell carcinoma (ESCC) is one of the most fatal malignancies in the world because progression occurs without symptoms and many patients are malnourished at the time of diagnosis $(1,2)$. It is well known that lymph node (LN) metastasis correlates with a poor outcome for ESCC patients (3). In treatment of advanced ESCC with LN metastasis, surgery remains the best palliation for patients; however, the 5 -year survival rate is $\sim 20 \%$ (4). This poor outcome may be explained in part by the fact that it remains unclear how LN metastasis develops and which genes are involved in the process. Tumorigenesis is a complex, multistage process that involves many genes. Therefore, analysis of gene expression patterns in ESCC is necessary in order to develop diagnostic, prognostic and therapeutic tools to improve outcome.

DNA microarrays have been used to comprehensively analyze many genes involved in the pathogenesis of various malignancies (5). This technology has made it possible to predict the cancer outcome accurately $(6,7)$.

With respect to ESCC, there have been many DNA microarray studies identifying genes related to pathogenesis or therapy of ESCC (8-16); however, only two studies considered and analyzed LN metastasis $(17,18)$. Kan et al $(17)$ reported that molecular profiling of 60 genes accurately predicted LN metastasis in 10 of $13(77 \%)$ ESCCs. Molecular profiling by Tamoto et al (18) correctly predicted LN metastasis in 16 of $18(89 \%)$ ESCCs. However, in these studies $(17,18)$, the number of samples tested was too small to validate the predictive performance or to clarify the molecular basis of LN metastasis. To resolve these issues, molecular profiling of a larger number of samples is needed.

In the present study, we used high-density oligonucleotide microarray to identify LN metastasis-related genes in a large number of ESCC $(n=54)$ and non-cancerous esophageal tissues $(n=11)$. We focused in particular on the relation between invasion depth and LN metastasis and then classified the ESCC 
Table I. Clinicopathological features.

\begin{tabular}{|c|c|c|c|c|c|c|}
\hline Factors & Non-cancerous tissue & $\mathrm{pT} 1 / \mathrm{pN} 0$ & $\mathrm{pT} 1 / \mathrm{pN} 1$ & pT2-4/pN0 & pT2-4/pN1 & P-value \\
\hline Gender (male/female) & $11 / 0$ & $9 / 0$ & $9 / 1$ & $6 / 1$ & $24 / 4$ & NS \\
\hline Age $($ mean \pm SD) & $62.0 \pm 9.1$ & $64.1 \pm 9.0$ & $59.9 \pm 7.5$ & $60.1 \pm 7.8$ & $63.4 \pm 12.1$ & NS \\
\hline Histological grading $(\mathrm{G} 1 / \mathrm{G} 2 / \mathrm{G} 3)^{\mathrm{a}}$ & & $1 / 6 / 2$ & $3 / 5 / 2$ & $4 / 2 / 1$ & $8 / 12 / 8$ & NS \\
\hline No. of involved lymph nodes (mean \pm SD) & & - & $3.2 \pm 2.7$ & - & $4.68 \pm 2.9$ & NS \\
\hline
\end{tabular}

${ }^{a}$ G1, well-differentiated tumor; G2, moderately-differentiated tumor; G3, poorly-differentiated tumor by TNM classification (24). NS, not significant.

samples into four different tumor classes according to degree of invasive depth (pT1 vs. pT2-4) and the presence or absence of LN metastasis (pN0 vs. pN1). We used our original supervised learning method (19-23) to compare genes whose expression differed significantly between the four tumor classes and the non-cancerous tissue. Our gene expression profiles provide new insights into the mechanisms underlying carcinogenesis and progression of ESCC, particularly LN metastasis.

\section{Materials and methods}

Patients. Fifty-four patients underwent surgical treatment for ESCC at Yamaguchi University Hospital between September 1997 and March 2003; none had undergone prior chemotherapy or radiotherapy. Preoperative imaging analysis revealed that no patient had distant metastases at the time of surgery. Written informed consent was obtained from all patients prior to surgery. The study protocol was approved by the Institutional Review Board for the Use of Human Subjects at the Yamaguchi University School of Medicine. All ESCC was diagnosed histopathologically by at least two trained pathologists. Tumor stage and grade were classified according to the pTNM Classification of the International Union Against Cancer (24). Eleven nontumorous esophageal samples from 11 patients who underwent esophageal resection and who had histologically normal esophageal mucosa were included as control.

DNA microarray analysis. Each cancer tissue sample was divided into two specimens; one part was frozen in liquid nitrogen immediately after surgical resection, and the other part was used for histopathological examination. The clinical and pathologic data for these patients are summarized in Table I. RNA extractions, cDNA and cRNA syntheses and oligonucleotide microarray screening were performed as described previously with minor modifications $(6,19)$. In the present study, we used the Human Genome U133 A ${ }^{\circledR}$ DNA microarray chip (Affymetrix, Santa Clara, CA), which contains 22,115 genes.

Digitized image data from the microarray chip were processed using Affymetrix ${ }^{\circledR}$ Microarray Suite 5.0 software, and initial absolute analysis was performed without scaling. For comparative analyses using Roche Affymetrix Chip Experiment-Analysis (RACE-A) software, the average fluorescence intensity of all the genes on each chip was set to

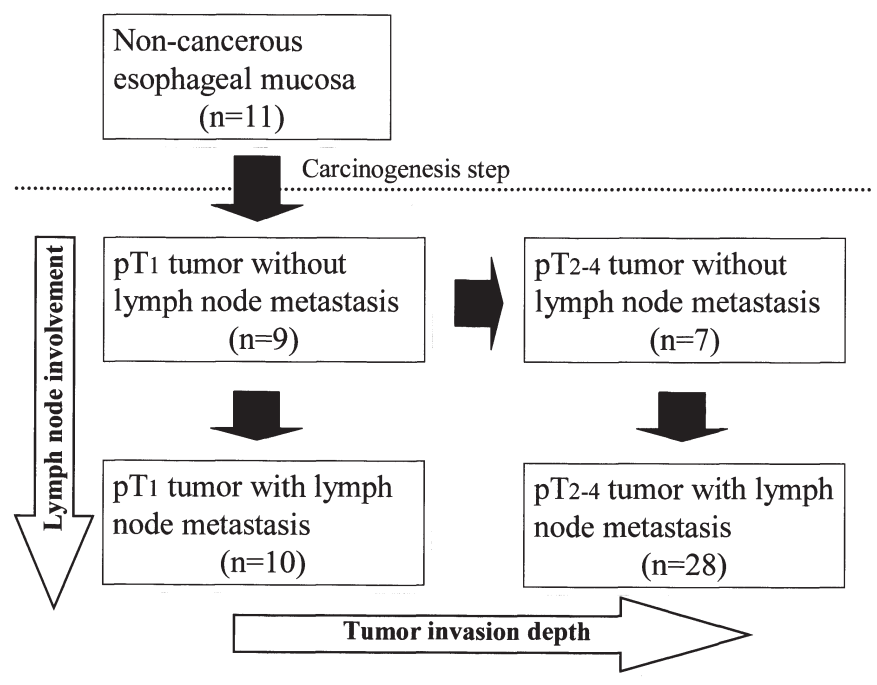

Figure 1. Schematic carcinogenesis and progression of ESCC. We classified the 65 esophageal tissues into five groups on the basis of tumor invasive depth and LN involvement, and then compared gene expression variations between groups using our original supervised learning theory (see Materials and methods).

1000. We then used the average difference of the hybridization signal, which measures the mean difference in fluorescence intensity between a perfect match and centrally mismatched oligonucleotides of a probe set.

Gene selection. We first selected genes that had all present call (arbitrary units by Affymetrix) in all 54 ESCC samples and 11 non-tumorous esophageal mucosa samples. This filtering resulted in the identification of 4,155 genes (18.8\%) of the 22,115 genes. We then profiled genes among noncancerous esophageal tissues and the four classes of ESCC (Fig. 1). We used the Fisher ratio $(6,19-23)$ to evaluate the abilities of the selected genes to discriminate non-cancerous esophageal tissue $(n=11)$ and pT1/pN0 tumors $(n=9), p T 1 /$ $\mathrm{pN} 0$ tumors and $\mathrm{pT} 1 / \mathrm{pN} 1$ tumors $(\mathrm{n}=10), \mathrm{pT} 1 / \mathrm{pN} 0$ tumors and $\mathrm{pT} 2-4 / \mathrm{pN} 0$ tumors $(\mathrm{n}=7)$, and $\mathrm{pT} 2-4 / \mathrm{pN} 0$ tumors and $\mathrm{pT} 2-4 / \mathrm{pN} 1$ tumors $(\mathrm{n}=28)$.

\section{Results}

To examine changes in gene expression in ESCC related to different clinicopathological characteristics, we performed 
Table II. Top 30 genes whose expression levels differed between non-cancerous tissue and pT1 tumors without lymph node metastasis.

Fisher ratio Fold change Accession no. Abbreviation Locus Function

\begin{tabular}{clllll}
\multicolumn{5}{c}{ Thirteen genes up-regulated in pT1 tumors without lymph node metastasis } \\
12.874 & 2.393 & D26600 & PSMB4 & $1 \mathrm{q} 21$ & Ubiquitination \\
12.346 & 3.577 & D26361 & KIF14 & $1 \mathrm{pter}-\mathrm{q} 31.3$ & Microtubule associated complex \\
11.010 & 2.617 & D38551 & RAD21 & $8 \mathrm{q} 24$ & Apoptosis, cell cycle, cell motility \\
10.899 & 1.867 & U75503 & ADAR & $1 \mathrm{q} 21.1-\mathrm{q} 21.2$ & Double-stranded RNA adenosine deaminase activity \\
9.945 & 1.959 & BC022432 & SNRPG & $2 \mathrm{p} 13.3$ & Small nucleolar ribonucleoprotein complex \\
9.188 & 2.003 & D26598 & PSMB3 & $17 \mathrm{q} 12$ & Ubiquitination \\
9.034 & 2.005 & G54029 & PSMB4 & $1 \mathrm{q} 21$ & Ubiquitination \\
8.889 & 2.340 & D78151 & PSMD2 & $3 \mathrm{q} 27.3$ & Ubiquitination \\
8.818 & 2.563 & AF001212 & PSMD11 & $17 \mathrm{q} 12$ & Ubiquitination \\
8.674 & 1.993 & X78669 & RCN2 & $15 \mathrm{q} 23$ & Calcium-binding protein \\
8.345 & 1.782 & J03827 & NSEP1 & $1 \mathrm{p} 34$ & DNA-binding protein B \\
8.222 & 2.162 & L77701 & COX17 & $3 \mathrm{q} 13.33$ & Intracellular copper ion transporter \\
8.135 & 2.166 & X65867 & ADSL & $22 \mathrm{q} 13.2$ & Purine ribonucleotide biosynthesis
\end{tabular}

Seventeen genes down-regulated in pT1 tumor without lymph node metastasis

\begin{tabular}{rlllll}
25.798 & 0.299 & BC003370 & CSTB & $21 \mathrm{q} 22.3$ & Cysteine protease inhibitor activity \\
21.042 & 0.199 & Y07909 & EMP1 & $12 \mathrm{p} 12.3$ & Cell proliferation \\
14.871 & 0.554 & BF683426 & & & Unknown \\
13.199 & 0.362 & X05908 & ANXA1 & $9 \mathrm{q} 12-\mathrm{q} 21.2$ & Cell motility \\
11.827 & 0.338 & AB067506 & KIAA1919 & $6 \mathrm{q} 21$ & Unknown \\
11.748 & 0.487 & U10248 & RPL29 & $3 \mathrm{p} 21.3-\mathrm{p} 21.2$ & Structural protein of ribosome \\
10.950 & 0.336 & L33930 & CD24 & $6 \mathrm{q} 21$ & Cell adhesion \\
10.816 & 0.523 & U70063 & ASAH1 & $8 \mathrm{p} 22-\mathrm{p} 21.3$ & Fatty acid metabolism \\
9.898 & 0.228 & L05187 & SPRR1A & $1 \mathrm{q} 21-\mathrm{q} 22$ & Structural molecule activity \\
9.885 & 0.186 & M18216 & CEACAM6 & $19 \mathrm{q} 13.2$ & Cell-cell signaling \\
9.585 & 0.294 & AY007220 & S100A14 & $1 \mathrm{q} 21.1$ & Calcium ion binding \\
9.488 & 0.385 & N92498 & & & Unknown \\
9.372 & 0.242 & M93056 & SERPINB1 & $6 \mathrm{p} 25$ & Serine protease inhibitor activity \\
8.982 & 0.389 & L33930 & CD24 & $6 \mathrm{q} 21$ & Cell adhesion \\
8.940 & 0.415 & X05978 & CSTA & $3 \mathrm{q} 21$ & Cysteine protease inhibitor activity \\
8.275 & 0.373 & M58664 & CD24 & $6 \mathrm{q} 21$ & Cell adhesion \\
8.025 & 0.603 & BC047024 & SUCLG2 & $3 \mathrm{p} 14.3$ & Succinyl-CoA synthetase, B-G chain \\
\hline
\end{tabular}

Fold change, average of pT1 tumors without lymph node metastasis/non-cancerous tissue. Accession nos. and abbreviations were obtained from the URL website (http://www.ncbi.nih.gov/entrez/query.fcgi?db=gene).

microarray analysis of 22,115 and found that 4,155 were differentially expressed in ESCC. For each comparison, we ranked the identified 4,155 genes in order of decreasing magnitude of the Fisher ratio. To determine the number of genes that should be considered, we performed a random permutation test as described previously (19-23). From the distribution of the Fisher ratios based on the randomized data, we selected all genes that passed the random permutation test $(\mathrm{P}<0.01)$. We found that the levels of expression of 999 genes with Fisher ratios greater than 1.54 differed significantly between $\mathrm{pT} 1 / \mathrm{pN} 0$ tumors and non-cancerous esophageal tissue. Information for the top 100 genes listed here is available in the supplementary Tables. In the same manner, 48 (Fisher ratio >1.65), 66 (Fisher ratio >2.10) and 30 (Fisher ratio $>1.34$ ) genes showed differential expression in $\mathrm{pT} 1 / \mathrm{pN} 0$ tumors vs. $\mathrm{pT} 1 / \mathrm{pN} 1$ tumors, $\mathrm{pT} 1 / \mathrm{pN} 0$ tumors vs. pT2-4/pN0 tumors and pT2-4/pN0 tumors vs. pT2-4/pN1 tumors, respectively (supplementary Tables). Tables II-V and Fig. 2 show the 30 genes with the highest Fisher ratios in each comparison. These genes had various biological functions.

Interestingly, there were no overlaps between the $48 \mathrm{LN}$ metastasis-related genes of pT1 tumors and the $30 \mathrm{LN}$ meta- 
Table III. Top 30 genes whose expression levels differed between pT tumors without lymph node metastasis and pT1 tumors with lymph node metastasis.

\begin{tabular}{cccccl}
\hline Fisher ratio & Fold change & Accession no. & Abbreviation & Locus & Function \\
\hline \multicolumn{7}{l}{ Five genes up-regulated in pT1 tumors with lymph node metastasis } \\
2.783 & 1.495 & AA789278 & & Unknown & Unknown \\
2.457 & 1.425 & AF077043 & RPL36 & $19 \mathrm{p} 13.3$ & Structural constituent of ribosome \\
2.313 & 1.307 & X64707 & RPL13 & $16 \mathrm{q} 24.3$ & Structural constituent of ribosome \\
2.257 & 1.376 & AW574664 & & Unknown & Unknown \\
1.992 & 1.359 & Z98200 & & Unknown & Unknown
\end{tabular}

Twenty-five genes down-regulated in pT1 tumors with lymph node metastasis

\begin{tabular}{|c|c|c|c|c|c|}
\hline 4.473 & 0.561 & AF054174 & $\mathrm{H} 2 \mathrm{AFY}$ & $5 q 31.3-q 32$ & Chromosome organization and biogenesis \\
\hline 3.954 & 0.648 & AB023229 & KIAA1012 & $18 \mathrm{q} 12.1$ & Intracellular transporter activity \\
\hline 3.701 & 0.612 & L09604 & PLP2 & Xp11.23 & A4 differentiation-dependent protein \\
\hline 3.637 & 0.558 & ВC015178 & C18orf10 & $18 \mathrm{q} 12.2$ & Unknown, DKFZP586M1523 protein \\
\hline 3.154 & 0.695 & BC002939 & MCLC & $1 \mathrm{p} 13.3$ & Unknown, Mid-1-related chloride channel 1 \\
\hline 2.911 & 0.682 & AF380179 & SON & $21 \mathrm{q} 22.11$ & Anti-apoptosis \\
\hline 2.863 & 0.646 & ВC014840 & MADH2 & $18 \mathrm{q} 21.1$ & Regulation of transcription \\
\hline 2.724 & 0.673 & AF351618 & FBXO11 & $2 \mathrm{p} 21$ & Ubiquitin conjugating enzyme activity \\
\hline 2.706 & 0.595 & AJ007590 & $\mathrm{RP} 2$ & Xp11.4-p11.21 & ß-tubulin folding \\
\hline 2.674 & 0.614 & P56211 & ARPP-19 & $15 \mathrm{q} 21.1$ & Positive regulation of glucose import \\
\hline 2.666 & 0.638 & AK001152 & FLJ10290 & $5 q 33.1$ & Nucleic acid binding \\
\hline 2.607 & 0.727 & U39317 & UBE2D2 & $5 q 31.3$ & Invasive growth, ubiquitin-conjugating enzyme \\
\hline 2.481 & 0.727 & L23805 & CTNNA1 & $5 q 31$ & Cell adhesion molecule activity \\
\hline 2.444 & 0.708 & U83117 & UBL1 & $2 q 33$ & Ubiquitin conjugating enzyme activity \\
\hline 2.318 & 0.557 & D64110 & BTG3 & $21 \mathrm{q} 21.1-\mathrm{q} 21.2$ & Negative regulation of cell proliferation \\
\hline 2.271 & 0.715 & AF063015 & FTSJ1 & Xp11.23 & Cell division protein \\
\hline 2.267 & 0.629 & AK000101 & $\mathrm{ZCCHC10}$ & $5 q 31.1$ & Unknown, nucleic acid binding \\
\hline 2.241 & 0.734 & AF100615 & MORF4L1 & $15 \mathrm{q} 24$ & Regulation of cell growth \\
\hline 2.214 & 0.680 & AL122045 & CNOT8 & $5 q 31-q 33$ & Regulation of transcription \\
\hline 2.206 & 0.734 & J04977 & XRCC5 & $2 q 35$ & Unknown, DNA recombination \\
\hline 2.106 & 0.649 & M16827 & ACADM & $1 \mathrm{p} 31$ & Fatty acid metabolism \\
\hline 2.046 & 0.747 & AB030181 & ARID4B & $1 \mathrm{q} 42.1-\mathrm{q} 43$ & Retinoblastoma-binding protein 1-like 1 \\
\hline 2.013 & 0.691 & M74525 & UBE2B & $5 q 23-q 31$ & Ubiquitin conjugating enzyme activity \\
\hline 1.983 & 0.630 & AL136810 & TIP120A & $12 q 14$ & TIP120 protein \\
\hline 1.960 & 0.709 & O43189 & PHF1 & $6 \mathrm{p} 21.3$ & Regulation of transcription \\
\hline
\end{tabular}

Fold change, average of pT1 tumors with lymph node metastasis/pT1 tumors without lymph node metastasis. Accession nos. and abbreviations were obtained from the URL website (http://www.ncbi.nih.gov/entrez/query.fcgi?db=gene).

stasis-related genes of pT2-4 tumors, suggesting that ESCCs with distinct invasive depths have different genetic pathways linked to LN metastasis.

\section{Discussion}

Despite recent surgical improvements, the prognosis of ESCC patients remains poor, with a 5-year survival rate of $\sim 20 \%$ (4). LN metastasis is one factor that strongly affects the outcome of ESCC (3). It was also reported that the degree of invasive depth of a tumor is closely related to LN metastasis in ESCC (25). In the present study, to elucidate the molecular basis of LN metastasis of ESCC, we examined gene expression patterns from two viewpoints: invasion depth of tumor and LN metastasis. We found that pT1 ESCCs and pT2-4 ESCCs do not commonly express any genes linked to LN metastasis (supplementary Tables). This result suggests that prediction of LN metastasis of ESCC on the basis of expression profiles is limited unless we consider the depth of tumor invasion. This concept is supported by the results of previous studies in which molecular profiling misclassified the presence or absence of LN metastasis in $3(23 \%)$ of 13 ESCCs (17) and $2(11 \%)$ of 18 
Table IV. Top 30 genes whose expression levels differed between pT1 tumors without lymph node metastasis and pT2-4 tumors without lymph node metastasis.

Fisher ratio Fold change Accession no. Abbreviation Locus Function

Fourteen genes up-regulated in pT2-4 tumors without lymph node metastasis

\begin{tabular}{|c|c|c|c|c|c|}
\hline 6.575 & 2.007 & G09498 & MYO1B & $2 q 12-q 34$ & Unknown, myosin-I $\alpha$ \\
\hline 5.600 & 1.602 & U61734 & TMP21 & $14 \mathrm{q} 24.3$ & Intracellular protein transport \\
\hline 4.782 & 1.659 & AF151893 & TTC11 & $7 q 22.1$ & Tetratricopeptide repeat domain 11 \\
\hline 4.515 & 1.607 & U84371 & AK2 & $1 \mathrm{p} 34$ & Adenylate kinase, mitochondrial \\
\hline 3.907 & 1.350 & AK000120 & OTUB1 & $11 \mathrm{q} 13.1$ & Ubiquitin-specific protease otubain 1 \\
\hline 3.559 & 2.561 & M14328 & ENO1 & $1 \mathrm{p} 36.3-\mathrm{p} 36.2$ & Negative regulation of transcription \\
\hline 3.443 & 1.535 & ВC002475 & PFN1 & $17 \mathrm{p} 13.3$ & Cytoskeleton organization and biogenesis \\
\hline 3.387 & 2.268 & L42584 & KRT6B & $12 q 12-q 13$ & Structural constituent of cytoskeleton \\
\hline 3.111 & 1.681 & K03515 & GPI & $19 \mathrm{q} 13.1$ & Humoral immune response, cytokine activity \\
\hline 2.906 & 1.777 & ВC010273 & PAICS & 4 pter-q21 & Purine nucleotide biosynthesis \\
\hline 2.827 & 1.367 & ВС008926 & RPL29 & $3 \mathrm{p} 21.3-\mathrm{p} 21.2$ & Structural protein of ribosome \\
\hline 2.812 & 1.864 & M86400 & YWHAZ & $8 \mathrm{q} 23.1$ & Protein domain specific binding \\
\hline 2.764 & 1.621 & AL117616 & SRI & $7 q 21.1$ & Calcium channel regulator \\
\hline 2.730 & 1.612 & ВС010430 & NSEP1 & $1 \mathrm{p} 34$ & Major histocompatibility complex, class II \\
\hline
\end{tabular}

Sixteen genes down-regulated in pT2-4 tumors without lymph node metastasis

\begin{tabular}{|c|c|c|c|c|c|}
\hline 9.543 & 0.639 & Q13618 & CUL3 & $2 q 36.3$ & Induction of apoptosis by intracellular signals \\
\hline 5.079 & 0.412 & AA486366 & RGS5 & $1 \mathrm{q} 23.1$ & Peripheral plasma membrane protein \\
\hline 4.799 & 0.561 & AL021366 & PHF1 & $6 \mathrm{p} 21.3$ & Regulation of transcription, DNA-dependent \\
\hline 4.113 & 0.581 & AF351618 & FBXO11 & $2 \mathrm{p} 21$ & Ubiquitin conjugating enzyme activity \\
\hline 4.078 & 0.572 & M16827 & ACADM & $1 \mathrm{p} 31$ & Fatty acid $\beta$-oxidation \\
\hline 3.540 & 0.435 & X76732 & NUCB2 & $11 \mathrm{p} 15.1-\mathrm{p} 14$ & Nucleobindin 2 \\
\hline 3.389 & 0.719 & AF251063 & $\mathrm{P} 17.3$ & Xp11.3 & Neuronal protein 17.3 \\
\hline 3.346 & 0.396 & D16360 & GPX3 & $5 q 23$ & Glutathione peroxidase activity \\
\hline 3.323 & 0.707 & AF044321 & COX11 & $17 \mathrm{q} 22$ & Cytochrome c oxidase biogenesis \\
\hline 3.198 & 0.738 & AA443738 & HBXIP & $1 \mathrm{p} 13.2$ & Viral replication, invasive growth \\
\hline 2.978 & 0.686 & AF315687 & AHCYL1 & $1 \mathrm{p} 12$ & Dendritic cell expressed AHCY-like protein \\
\hline 2.930 & 0.572 & AF092135 & CRI1 & $15 \mathrm{q} 21.1-\mathrm{q} 21.2$ & Chromosome 15 open reading frame 3 \\
\hline 2.830 & 0.512 & J03600 & ALOX5 & $10 \mathrm{q} 11.2$ & Lipoxygenase activity \\
\hline 2.780 & 0.617 & M15182 & GUSB & $7 q 21.11$ & Glycosaminoglycan catabolism \\
\hline 2.765 & 0.541 & AF176085 & РТВP2 & $1 \mathrm{p} 22.1-\mathrm{p} 21.3$ & Neural polypyrimidine tract binding protein \\
\hline 2.710 & 0.602 & AF251038 & C5orf5 & $5 q 31$ & Unknown, chromosome 5 open reading frame 5 \\
\hline
\end{tabular}

Fold change, average of pT2-4 tumors without lymph node metastasis/pT2-4 tumors with lymph node metastasis. Accession nos. and abbreviations were obtained from the URL website (http://www.ncbi.nih.gov/entrez/query.fcgi?db=gene).

ESCCs (18). Thus, in conjunction with our present finding, we propose that predictors for LN metastasis in ESCC should be established separately according to tumor invasion depth (pT1 and pT2-4) to obtain high predictive ability in a large cohort.

It is clinically important to accurately predict LN metastasis in pT1 ESCC to avoid unnecessary treatment of patients who have been cured by resection alone. In addition, elucidating the molecular basis of LN metastasis in this type of ESCC may identify new therapeutic targets. We found that the levels of 25 of the top 30 genes were lower in pT1/N1 ESCC than in pT1/N0 ESCC and that these 25 down-regulated genes were involved in various biological function activities (Table III). The five up-regulated genes included RPL36 and RPL13, both of which are structural components of ribosomes. It was reported that the levels of expression of many $R P L$ family genes were altered in ESCC cells showing acquired resistance to the anti-cancer agent cisplatin (12). Thus, it is possible that both RPL36 and RPL13 may be involved in LN metastasis of pT1 ESCC.

No angiogenesis-related genes showed differential expression when we compared pT1/pN0 ESCC and pT1/ pN1 ESCC. In contrast, expression levels of $V E G F$ were 
Table V. Top 30 genes whose expression levels differed between pT2-4 tumors without lymph node metastasis and pT2-4 tumors with lymph node metastasis.

\begin{tabular}{|c|c|c|c|c|c|}
\hline Fisher ratio & Fold change & Accession no. & Abbreviation & Locus & Function \\
\hline \multicolumn{6}{|c|}{ Seventeen genes upregulated in pT2-4 tumors with lymph node metastasis } \\
\hline 2.654 & 1.616 & AF389880 & $\mathrm{RC} 3$ & $15 q 15.3$ & Rabconnectin-3 \\
\hline 2.620 & 1.530 & ВC034418 & FLJ20719 & $1 \mathrm{p} 31$ & Unknown, hypothetical protein FLJ20719 \\
\hline 2.534 & 1.964 & BC059385 & UBL3 & $13 q 12-q 13$ & Ubiquitin-like 3 \\
\hline 2.392 & 1.523 & X80115 & NOTCH2 & 1p13-p11 & Notch 2 preproprotein \\
\hline 2.039 & 1.448 & O94806 & PRKCN & $2 \mathrm{p} 21$ & Protein amino acid phosphorylation \\
\hline 1.929 & 1.829 & AW516297 & FLJ11946 & Unknown & Unknown, hypothetical protein FLJ20719 \\
\hline 1.686 & 1.563 & M15182 & GUSB & $7 q 21.11$ & ß-glucuronidase activity \\
\hline 1.682 & 1.347 & AF047442 & SEC22L1 & $1 \mathrm{q} 21.2-\mathrm{q} 21.3$ & Unknown, hypothetical protein DJ328E19.C1.1 \\
\hline 1.660 & 1.392 & AF113124 & FEZ2 & $2 \mathrm{p} 21$ & Fasciculation and elongation protein $\zeta 2$ \\
\hline 1.636 & 1.504 & U77493 & NOTCH2 & 1p13-p11 & Unknown, notch 2 preproprotein \\
\hline 1.622 & 1.482 & AK001016 & FLJ10154 & $13 q 33.2$ & Unknown, hypothetical protein FLJ10154 \\
\hline 1.543 & 1.647 & M63978 & VEGF & $6 \mathrm{p} 12$ & Vascular endothelial growth factor receptor binding \\
\hline 1.463 & 1.688 & G28996 & FLJ20719 & Unknown & Unknown, hypothetical protein FLJ20719 \\
\hline 1.442 & 1.385 & AK024685 & SCD4 & $4 q 21.3$ & Stearoyl-CoA desaturase 4 \\
\hline 1.435 & 1.260 & AK025605 & ZDHHC6 & $10 \mathrm{q} 25.3$ & DHHC domain containing 6 , integral to membrane \\
\hline 1.408 & 1.471 & W72053 & FLJ21904 & Unknown & Unknown \\
\hline 1.394 & 1.967 & AB018298 & SEC24D & $4 q 27$ & Protein transport protein Sec24D \\
\hline
\end{tabular}

Thirteen genes downregulated in pT2-4 tumors with lymph node metastasis

\begin{tabular}{llllll}
2.611 & 0.743 & BC017218 & PLA2G12A & $4 \mathrm{q} 25$ & Lipid catabolism \\
2.268 & 0.648 & BF215996 & MYO1B & $2 \mathrm{q} 12-\mathrm{q} 34$ & Myosin-I $\alpha$ \\
2.188 & 0.715 & U84371 & AK2 & $1 \mathrm{p} 34$ & Adenylate kinase activity \\
1.971 & 0.638 & L26318 & MAPK8 & $10 \mathrm{q} 11.23$ & Microtubule-based movement \\
1.945 & 0.673 & AF047434 & NDUFS5 & $1 \mathrm{p} 34.2-\mathrm{p} 33$ & Mitochondrial electron transport \\
1.844 & 0.741 & BC002475 & PFN1 & $17 \mathrm{p} 13.3$ & Cytoskeleton organization and biogenesis \\
1.719 & 0.597 & U90906 & HSPB1 & $7 \mathrm{q} 11.23$ & Heat shock protein \\
1.603 & 0.745 & M27132 & ATP5B & $12 \mathrm{p} 13-\mathrm{qter}$ & ATP synthesis coupled proton transport \\
1.517 & 0.768 & D14878 & C10orf7 & $10 \mathrm{p} 13$ & Positive regulation of cell proliferation \\
1.448 & 0.715 & U66669 & HIBCH & $2 \mathrm{q} 32.3$ & Unknown, 3-hydroxyisobutyryl-CoA hydrolase activity \\
1.409 & 0.766 & AK074302 & FLJ21901 & $2 \mathrm{q} 31$ & Unknown, hypothetical protein FLJ21901 \\
1.395 & 0.721 & P05218 & OK/SW-c1.56 & $6 \mathrm{p} 21.32$ & Natural killer cell mediated cytolysis, B5-tubulin \\
1.368 & 0.749 & U63743 & KIF2C & $1 \mathrm{p} 34.1$ & Microtubule motor activity \\
\hline
\end{tabular}

Fold change, average of pT2-4 tumors with lymph node metastasis/pT2-4 tumors without lymph node metastasis. Accession nos. and abbreviations were obtained from the URL website(http://www.ncbi.nih.gov/entrez/query.fcgi?db=gene).

significantly higher in pT2-4/pN0 ESCC than in pT2-4/pN1 ESCC (Table V). It was reported that VEGF expression correlates with outcome and LN metastasis in ESCC (26). Interestingly, the percentage of VEGF-positive cells appears to increase with the invasive depth of ESCC (27). These reports support our finding that $V E G F$ is related to $\mathrm{LN}$ metastasis in pT2-4 ESCC but not in pT1 ESCC. In the present study, we also identified $\mathrm{NOTCH} 2$ as a gene responsible for $\mathrm{LN}$ metastasis of pT2-4 ESCC. Recent evidence shows that Notch signaling from tumor cells can activate endothelial cells and trigger tumor angiogenesis both in vitro and in a xenograft mouse tumor model and that selective interruption of Notch signaling within tumors may have anti-angiogenic effects (28). Collectively, these findings suggest that both VEGF and Notch play important roles in LN metastasis of pT2-4 ESCC via altered angiogenesis.

We found that 999 genes were expressed differentially between pT1/pNO ESCC and non-cancerous esophageal tissue, this number of genes was much larger than that from other comparisons between tumor classes, suggesting that the levels of many genes $(999 / 4,155,24 \%)$ change drastically during carcinogenesis. Several studies have examined the expression 


\section{A: Non-cancerous tissue vs. pT1/pN0 tumor}

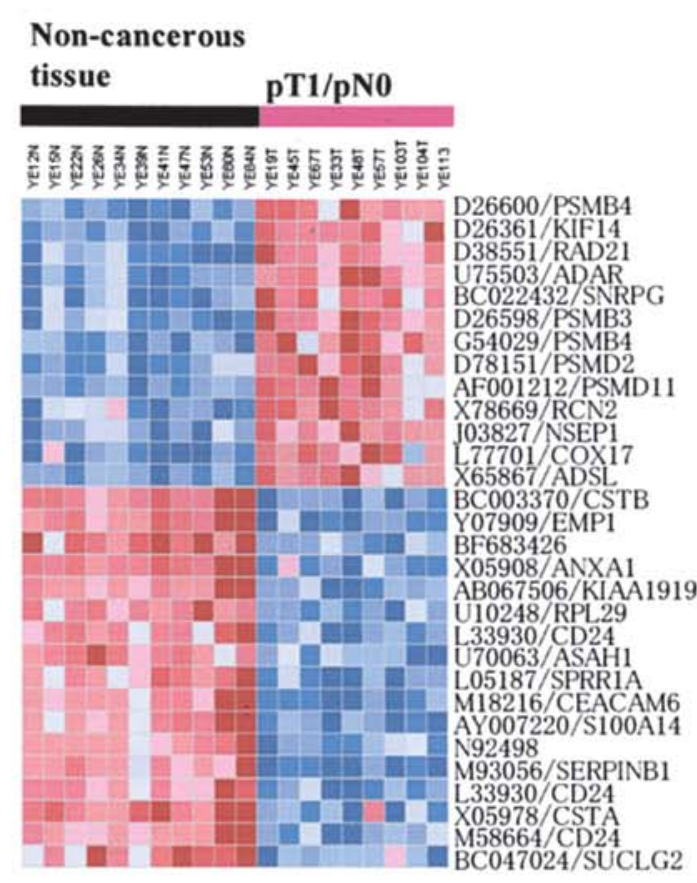

\section{C: pT1/pN0 tumor vs. pT2-4/pN0 tumor}

$\mathrm{pT} 1 / \mathrm{pN} 0 \quad \mathrm{pT2}-4 / \mathrm{pN} 0$

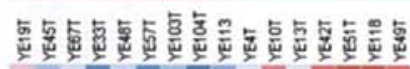

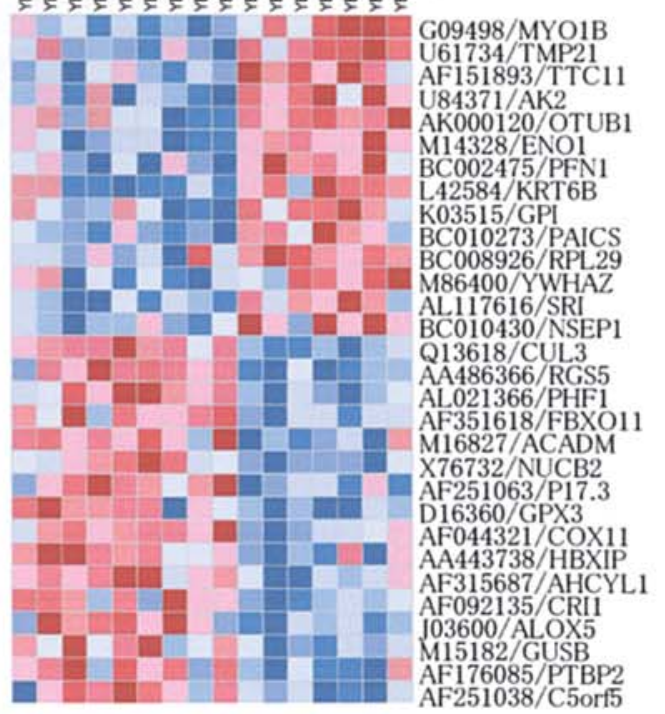

\section{B: pT1/pN0 tumor vs. pT1/pN1 tumor}

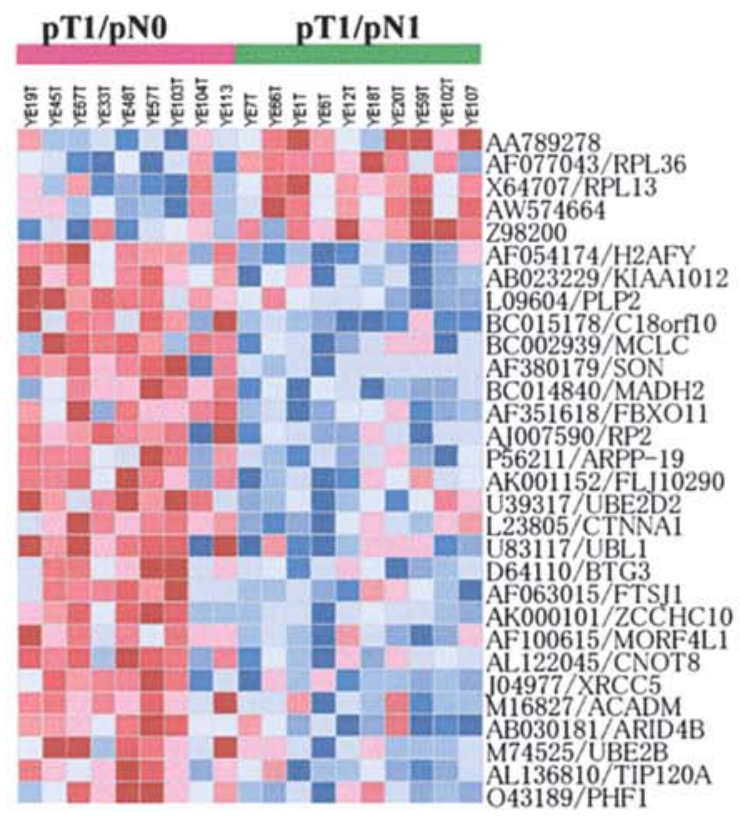

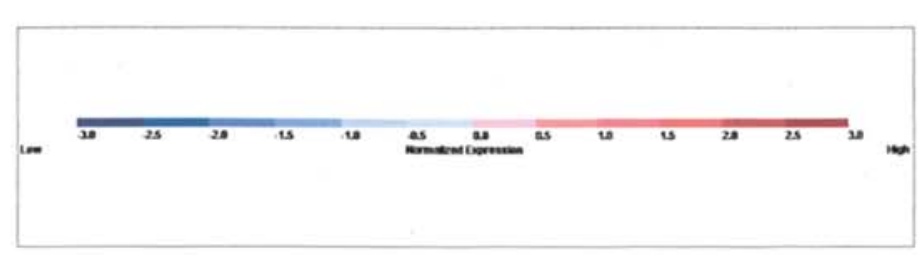

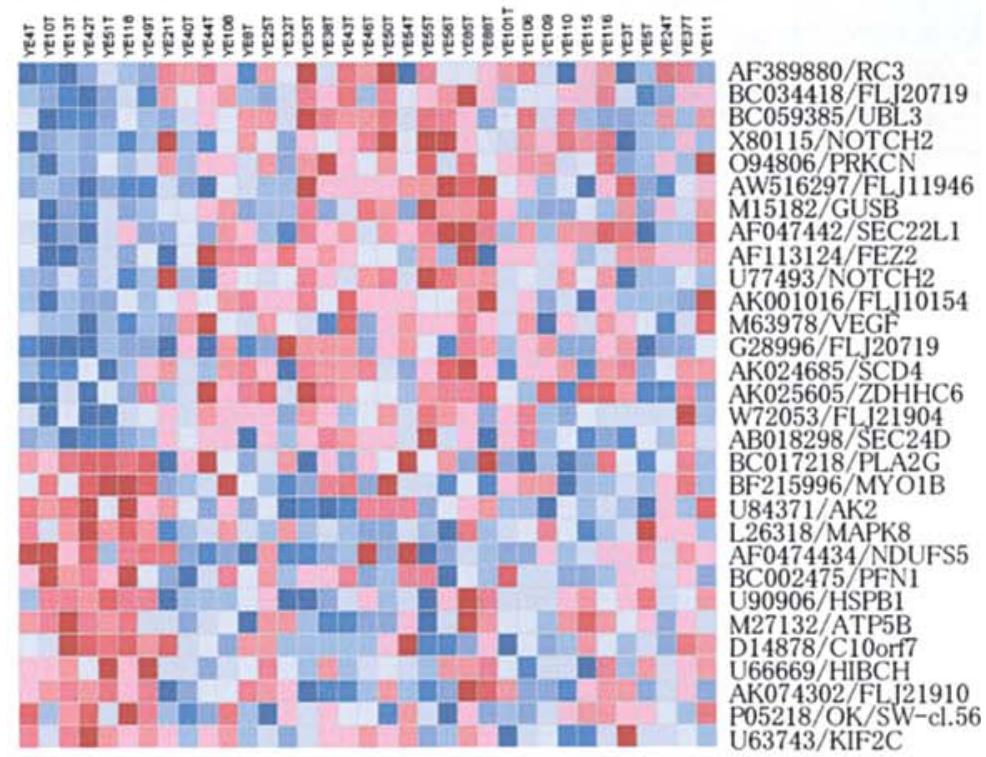

Figure 2. Genes linked to carcinogenesis and progression of ESCC. Color displays show the expression of the top 30 genes in pT1/pN0 tumors vs. noncancerous esophageal tissue (A), pT1/pN0 tumors vs. pT1/pN1 tumors (B), pT1/pN0 tumors vs. pT2-4/pN0 tumors (C) and pT2-4/pN0 tumors vs. pT2-4/pN1 tumors (D). Each gene was ranked in decreasing order of the Fisher ratio (see Materials and methods) and listed by accession no. and symbol, which were obtained from the Entrez Gene (http://www.ncbi.nih.gov/entrez/query.fcgi?db=gene) or TIGR database (http://www.tigr.org/tdb/hgi/searching/reports.html). 
of carcinogenesis-related genes in ESCC (8-10); however, all of these studies compared non-cancerous esophageal samples with heterogeneous ESCC samples consisting of pT1 to pT4 tumors with or without LN metastasis, resulting in a failure to identify key genes. Recently, it was reported that the number of differentially expressed genes dramatically increased in a step-by-step fashion from normal esophageal epithelium to papilloma, dysplasia and invasive carcinoma in a rat ESCC model (15). Because our present cohort did not include preneoplastic lesions such as papilloma and dysplasia, further studies are needed to identify genes with expression that differs between pre-neoplastic and non-cancerous esophageal tissues.

Among the 30 genes with differential expression between pT1/pN0 ESCC and non-cancerous esophageal tissues, increased expression of ubiquitination-related genes (PSMB3, PSMB4, PSMD2 and PSMD11) was the most characteristic gene signature (Table II). It was reported that levels of PSMB3 are increased in breast cancer (29). However, to our knowledge, there are no reports of up-regulation of expression of PSMB4, $P S M D 2$, or $P S M D 11$ in cancer. The ubiquitin pathway plays a central role in the regulation of cell growth and cell proliferation by degrading tumor suppressor proteins (30) and controlling the levels of key cell cycle proteins (31), suggesting that increased levels of ubiquitination-related genes may account for some growth advantage to cancer cells. Thus, the four genes described here may be molecular targets for prevention or treatment of ESCC.

In the present study, DNA microarray analysis revealed that many genes are involved in carcinogenesis and progression of ESCC. We also found that pT1 ESCC and pT2-4 ESCC express no common genes responsible for LN metastasis, raising the difficulty of accurate prediction of LN metastasis in ESCC without also considering tumor invasion depth. Further studies are needed to clarify whether this strategy can be used to predict LN metastasis in other types of cancer in the alimentary tract.

\section{Acknowledgements}

This work was supported in part by the New Energy and Industrial Technology Development Organization (NEDO) (No. 03A02018a).

\section{References}

1. Enzinger PC and Mayer RJ: Esophageal cancer. N Engl J Med 349: 2241-2252, 2003.

2. Oka M, Yamamoto K, Takahashi M, et al: Relationship between serum levels of interleukin 6 , various disease parameters and malnutrition in patients with esophageal squamous cell carcinoma. Cancer Res 56: 2776-2780, 1996.

3. Eloubeidi MA, Desmond R, Arguedas MR, et al: Prognostic factors for the survival of patients with esophageal carcinoma in the U.S: the importance of tumor length and lymph node status. Cancer 95: 1434-1443, 2002.

4. Ellis FH Jr: Standard resection for cancer of the esophagus and cardia. Surg Oncol Clin N Am 8: 279-294, 1999.

5. Chung $\mathrm{CH}$, Bernard PS and Perou CM: Molecular portraits and the family tree of cancer. Nat Genet 32: 533-540, 2002.

6. Iizuka N, Oka M, Yamada-Okabe H, et al: Oligonucleotide microarray for prediction of early intrahepatic recurrence of hepatocellular carcinoma after curative resection. Lancet 361 : 923-929, 2003.

7. Iizuka N, Hamamoto Y and Oka M: Predicting individual outcomes in hepatocellular carcinoma. Lancet 364: 1837-1839, 2004.
8. Lu J, Liu Z, Xiong M, et al: Gene expression profile changes in initiation and progression of squamous cell carcinoma of esophagus. Int J Cancer 91: 288-294, 2001

9. Hu YC, Lam KY, Law S, et al: Identification of differentially expressed genes in esophageal squamous cell carcinoma (ESCC) by cDNA expression array: overexpression of Fra-1, Neogenin, Id-1, and CDC25B genes in ESCC. Clin Cancer Res 7: 2213-2221, 2001

10. Lu J, Hu G, Wang X, et al: Cloning and characterization of a novel gene EC97 associated with human esophageal squamous cell carcinoma. Int J Mol Med 11: 243-247, 2003.

11. Zhou J, Zhao LQ, Xiong MM, et al: Gene expression profiles at different stages of human esophageal squamous cell carcinoma. World J Gastroenterol 9: 9-15, 2003.

12. Toshimitsu H, Hashimoto K, Tangoku A, et al: Molecular signature linked to acquired resistance to cisplatin in esophageal cancer cells. Cancer Lett 211: 69-78, 2004.

13. Fukuda K, Sakakura C, Miyagawa K, et al: Differential gene expression profiles of radioresistant oesophageal cancer cell lines established by continuous fractionated irradiation. $\mathrm{Br} \mathrm{J}$ Cancer 91: 1543-1550, 2004.

14. Luo A, Kong J, Hu G, et al: Discovery of $\mathrm{Ca}^{2+}$-relevant and differentiation-associated genes downregulated in esophageal squamous cell carcinoma using cDNA microarray. Oncogene 23: 1291-1299, 2004.

15. Nishida K, Mine S, Utsunomiya T, et al: Global analysis of altered gene expressions during the process of esophageal squamous cell carcinogenesis in the rat: a study combined with a laser microdissection and a cDNA microarray. Cancer Res 65: 401-409, 2005.

16. Kihara C, Tsunoda T, Tanaka T, et al: Prediction of sensitivity of esophageal tumors to adjuvant chemotherapy by cDNA microarray analysis of gene-expression profiles. Cancer Res 61: 6474-6479, 2001.

17. Kan T, Shimada Y, Sato F, et al: Prediction of lymph node metastasis with use of artificial neural networks based on gene expression profiles in esophageal squamous cell carcinoma. Ann Surg Oncol 11: 1070-1078, 2004.

18. Tamoto E, Tada M, Murakawa K, et al: Gene-expression profile changes correlated with tumor progression and lymph node metastasis in esophageal cancer. Clin Cancer Res 10: 3629-3638, 2004.

19. Iizuka N, Oka M, Yamada-Okabe H, et al: Comparison of gene expression profiles between hepatitis B virus- and hepatitis C virus-infected hepatocellular carcinoma by oligonucleotide microarray data based on a supervised learning method. Cancer Res 62: 3939-3944, 2002.

20. Iizuka N, Oka M, Yamada-Okabe H, et al: Molecular signature in three types of hepatocellular carcinoma with different viral origin by oligonucleotide microarray. Int J Oncol 24: 565574,2004 .

21. Iizuka N, Oka M, Yamada-Okabe H, et al: Self-organizingmap-based molecular signature representing the development of hepatocellular carcinoma. FEBS Lett 579: 1089-1100, 2005.

22. Takemoto N, Iizuka N, Yamada-Okabe H, et al: Sex-based molecular profiling of hepatitis $\mathrm{C}$ virus-related hepatocellular carcinoma. Int J Oncol 26: 673-678, 2005.

23. Matoba K, Iizuka N, Gondo T, et al: Tumor HLA-DR expression linked to early intrahepatic recurrence of hepatocellular carcinoma. Int J Cancer 115: 231-240, 2005.

24. Sobin LH and Wittekind C: TNM Classification of Malignant Tumours. 6th edition. UICC, Wiley-Liss, pp60-64, 2002.

25. Kuwano H, Nakajima M, Miyazaki T, et al: Distinctive clinicopathological characteristics in esophageal squamous cell carcinoma. Ann Thorac Cardiovasc Surg 9: 6-13, 2003.

26. Shih $\mathrm{CH}$, Ozawa S, Ando N, et al: Vascular endothelial growth factor expression predicts outcome and lymph node metastasis in squamous cell carcinoma of the esophagus. Clin Cancer Res 6: 1161-1168, 2000.

27. Fujii T, Sudo T, Sueyoshi S, et al: Clinicopathologic study of neovascularization and VEGF expression in superficial esophageal carcinoma. Int J Oncol 21: 1181-1187, 2002.

28. Li JL and Harris AL: Notch signaling from tumor cells: a new mechanism of angiogenesis. Cancer Cell 8: 1-3, 2005.

29. Dressman MA, Baras A, Malinowski R, et al: Gene expression profiling detects gene amplification and differentiates tumor types in breast cancer. Cancer Res 63: 2194-2199, 2003.

30. Sherr CJ: Principles of tumor suppression. Cell 116: 235-246, 2004.

31. Bashir T and Pagano M: Aberrant ubiquitin-mediated proteolysis of cell cycle regulatory proteins and oncogenesis. Adv Cancer Res 88: 101-144, 2003. 
Supplementary Table I. Top 100 genes whose expression levels differed between non-cancerous tissue and pT1 tumors without lymph node metastasis.

\begin{tabular}{|c|c|c|c|c|c|}
\hline Order & & & Gene Accession no. & Symbol & Function \\
\hline 1 & 201201_at & 1 & BC003370 & CSTB & Cysteine protease inhibitor activity \\
\hline 2 & 201324_at & 1 & Y07909 & EMP1 & Cell proliferation \\
\hline 3 & 213969_x_at & 1 & BF683426 & & Unknown \\
\hline 4 & 201012_at & 1 & X05908 & ANXA1 & Cell motility \\
\hline 5 & 202244_at & / & D26600 & PSMB4 & Ubiquitin-dependent protein catabolism \\
\hline 6 & 206364_at & / & D26361 & KIF14 & Microtubule associated complex \\
\hline 7 & 216379_x_at & 1 & AB067506 & KIAA1919 & Unknown, KIAA1919 protein \\
\hline 8 & 200823_x_at & 1 & U10248 & RPL29 & Structural protein of ribosome \\
\hline 9 & 200608_s_at & / & D38551 & RAD21 & Apoptosis, cell cycle, cell motility \\
\hline 10 & 266_s_at & 1 & L33930 & $\mathrm{CD} 24$ & Cell adhesion \\
\hline 11 & 201786_s_at & / & U75503 & ADAR & Double-stranded RNA adenosine deaminase activity \\
\hline 12 & 210980_s_at & 1 & U70063 & ASAH1 & Fatty acid metabolism \\
\hline 13 & 205644_s_at & / & BC022432 & SNRPG & Small nucleolar ribonucleoprotein complex \\
\hline 14 & 214549_x_at & 1 & L05187 & SPRR1A & Structural molecule activity \\
\hline 15 & 211657_at & 1 & M18216 & CEACAM6 & Cell-cell signaling \\
\hline 16 & 218677_at & 1 & AY007220 & S100A14 & Calcium ion binding \\
\hline 17 & 212593_s_at & 1 & N92498 & & Unknown \\
\hline 18 & 213572_s_at & 1 & M93056 & SERPINB1 & Serine protease inhibitor activity \\
\hline 19 & 201400_at & / & D26598 & PSMB3 & Ubiquitin-dependent protein catabolism \\
\hline 20 & 202243_s_at & / & G54029 & PSMB4 & Endopeptidase activity \\
\hline 21 & 208651_x_at & 1 & L33930 & $\mathrm{CD} 24$ & Humoral immune response \\
\hline 22 & 204971_at & 1 & X05978 & CSTA & Cysteine protease inhibitor activity \\
\hline 23 & 200830_at & / & D78151 & PSMD2 & Tumor necrosis factor receptor-associated protein 2 \\
\hline 24 & 208777_s_at & / & AF001212 & PSMD11 & $26 \mathrm{~S}$ proteasome regulatory subunit 9 \\
\hline 25 & 201486_at & / & X78669 & RCN2 & Calcium-binding protein \\
\hline 26 & 208628_s_at & / & J03827 & NSEP1 & DNA-binding protein B \\
\hline 27 & 209771_x_at & 1 & M58664 & $\mathrm{CD} 24$ & Humoral immune response \\
\hline 28 & 203880_at & / & L77701 & COX17 & Intracellular copper ion transporter \\
\hline 29 & 202144_s_at & / & X65867 & ADSL & Purine ribonucleotide biosynthesis \\
\hline 30 & 215772_x_at & 1 & $\mathrm{BC} 047024$ & SUCLG2 & Succinyl-CoA synthetase, $B-G$ chain \\
\hline 31 & 210999_s_at & / & U66065 & Grb10 & Cell-cell signaling \\
\hline 32 & 211939_x_at & 1 & X74070 & HSBTF3 & Regulation of transcription, DNA-dependent \\
\hline 33 & 201612_at & 1 & U34252 & ALDH9 & Aldehyde dehydrogenase (NAD+) activity \\
\hline 34 & 205394_at & / & AF016582 & CHK1 & Negative regulation of cell proliferation \\
\hline 35 & 202770_s_at & 1 & U47414 & CCNG2 & Cyclin G2, cell cycle, cytokinesis \\
\hline 36 & 202794_at & 1 & L08488 & INPP1 & Signal transduction \\
\hline 37 & 39248_at & 1 & N74607 & 1NFLS & Transport of nonionic small solutes \\
\hline 38 & 209369_at & 1 & M63310 & ANX3 & Phospholipase A2 inhibitor activity \\
\hline 39 & 202096_s_at & 1 & M36035 & BZRP & Mitochondrial translocation \\
\hline 40 & 201348_at & 1 & D00632 & GPX3 & Glutathione peroxidase activity \\
\hline 41 & 213699_s_at & / & X56468 & & Regulation of cell cycle \\
\hline 42 & 201637_s_at & / & $\mathrm{U} 25165$ & FXR1 & Fragile $\mathrm{X}$ mental retardation-related protein 1 \\
\hline 43 & 200703_at & 1 & U32944 & PIN & Microtubule motor activity \\
\hline 44 & 210142_x_at & / & AF117234 & FLOT1 & Integral to membrane \\
\hline 45 & 214091_s_at & 1 & M24613 & $\mathrm{PHO} 2$ & Unknown \\
\hline 46 & 201853_s_at & / & M25515 & CDC25B & Cell division cycle, regulation of cell cycle \\
\hline 47 & 214737_x_at & / & AV725195 & & Unknown \\
\hline 48 & 202537_s_at & 1 & AL080122 & HTC & Unknown, DKFZP564O123 protein \\
\hline 49 & 214328_s_at & / & R01140 & & Unknown \\
\hline 50 & 204751_x_at & 1 & Z15207 & DSC2 & Cell adhesion molecule activity \\
\hline 51 & 208517_x_at & 1 & DQ131479 & BTF3 & Regulation of transcription, DNA-dependent \\
\hline
\end{tabular}


Supplementary Table I. Continued.

\begin{tabular}{|c|c|c|c|c|c|}
\hline \multicolumn{2}{|l|}{ Order } & \multicolumn{2}{|c|}{ Gene Accession no. } & \multirow[t]{2}{*}{ Symbol } & \multirow[t]{2}{*}{ Function } \\
\hline 52 & 209932_s_at & / & U90223 & & \\
\hline 53 & 212586_at & 1 & AA195244 & & Proteolysis and peptidolysis \\
\hline 54 & 201528_at & / & M63488 & & DNA repair \\
\hline 55 & 221702_s_at & / & AF353992 & BLP2 & BBP-like protein 2 \\
\hline 56 & 201477_s_at & / & X59543 & RRM1 & DNA replication \\
\hline 57 & 202731_at & 1 & U96628 & PDCD4 & Programmed cell death 4 \\
\hline 58 & 210927_x_at & / & ВС004239 & MGC & Oncogenesis \\
\hline 59 & 211761_s_at & / & ВC005975 & MGC & Calcyclin binding protein \\
\hline 60 & 222229_x_at & 1 & AL121871 & RPL26 & Unknown, Pseudogene \\
\hline 61 & 202546_at & 1 & AF053233 & VAMP8 & Vesicle-associated membrane protein \\
\hline 62 & 204068_at & / & U60206 & STK3 & Protein amino acid phosphorylation, apoptosis \\
\hline 63 & 211026_s_at & 1 & ВС006230 & MGC & Lipid metabolism \\
\hline 64 & 212371_at & / & AL049397 & DKFZ & Unknown \\
\hline 65 & 200633_at & / & ВС006230 & UBB & Protein modification \\
\hline 66 & 212725_s_at & / & N37081 & & Unknown \\
\hline 67 & 210027_s_at & / & M80261 & APE & Multifunctional DNA repair enzyme \\
\hline 68 & 204219_s_at & / & L02426 & PSMC1 & $26 \mathrm{~S}$ proteasome \\
\hline 69 & 213929_at & 1 & AL050204 & & Unknown \\
\hline 70 & 209484_s_at & / & AF201941 & & Unknown, DKFZP566O1646 protein \\
\hline 71 & 203396_at & / & ВC005361 & PSMA4 & Ubiquitin-dependent protein catabolism \\
\hline 72 & 212372_at & / & AK026977 & MYH10 & Motor activity \\
\hline 73 & 212597_s_at & / & AL079310 & HS510H16B & Endosome to lysosome transport \\
\hline 74 & 212058_at & / & X54649 & DMFRIZZ2 & Ser/Arg-rich domain protein, RNA processing \\
\hline 75 & 208627_s_at & / & BE966374 & & Major histocompatibility complex, class II \\
\hline 76 & 208749_x_at & / & M33375 & HUMCCDR & Flotillin complex \\
\hline 77 & 201584_s_at & / & U90426 & DDXL & Nuclear RNA helicase \\
\hline 78 & 202605_at & / & M15182 & GUSB & Glycosaminoglycan catabolism \\
\hline 79 & 203432_at & / & U09086 & & Unknown, lamin/chromatin binding \\
\hline 80 & 201178_at & / & AF129537 & FBXO7 & Ubiquitin-dependent protein catabolism \\
\hline 81 & 202754_at & / & ВC041093 & KIAA0029 & Unknown, binds single-stranded nucleic acids \\
\hline 82 & 201433_s_at & l & D14694 & PTDSS & Unknown, phosphatidylserine synthase 1 \\
\hline 83 & 202983_at & / & AI760760 & & Regulation of transcription, DNA-dependent \\
\hline 84 & 201534_s_at & 1 & AF044221 & HCG-1 & Ubiquitin-like 3 \\
\hline 85 & 208091_s_at & / & ВC016650 & DKFZp564K0822 & Unknown, hypothetical protein DKFZp564K0822 \\
\hline 86 & 210574_s_at & l & AF241788 & NPD011 & Cell proliferation, regulation of cell cycle \\
\hline 87 & 208616_s_at & / & U48297 & PTPCAAX2 & Protein tyrosine phosphatase \\
\hline 88 & 218350_s_at & l & AL133264 & CLAPS3 & Negative regulation of DNA replication \\
\hline 89 & 212788_x_at & / & BG537190 & & Unknown \\
\hline 90 & 211208_s_at & / & AB039327 & CASK & Actin cytoskeleton, cell adhesion \\
\hline 91 & 211069_s_at & / & ВC006462 & SUMO1 & Ubiquitin conjugating enzyme activity \\
\hline 92 & 208771_s_at & 1 & J02959.1 & LTA4H & Proteolysis and peptidolysis \\
\hline 93 & 202246_s_at & l & U79269 & CDK4 & Cell proliferation, oncogenesis, regulation of cell cycle \\
\hline 94 & 219787_s_at & / & AK001323 & FLJ10461 & Cell growth and/or maintenance \\
\hline 95 & 211762_s_at & / & ВC005978 & RAG & Protein transporter activity \\
\hline 96 & 200965_s_at & 1 & D31883 & ABLIM & Cytoskeleton organization and biogenesis \\
\hline 97 & 200681_at & l & L07837 & GLO1 & Lactoylglutathione lyase \\
\hline 98 & 202666_s_at & / & AB015907 & BAF53A & Structural constituent of cytoskeleton \\
\hline 99 & 203255_at & / & AF264714 & VIT1 & Protein modification \\
\hline 100 & 200744_s_at & / & AI741124 & & RAS protein signal transduction \\
\hline
\end{tabular}

/, up-regulated genes in pT1 tumors without lymph node metastasis; \, down-regulated genes in pT1 tumors without lymph node metastasis. 
Supplementary Table II. Top 48 genes whose expression levels differed between pT tumors without lymph node metastasis and pT1 tumors with lymph node metastasis.

\begin{tabular}{|c|c|c|c|c|c|}
\hline Order & & & Gene Accession no. & Symbol & Function \\
\hline 1 & 207168_s_at & $\backslash$ & AF054174 & H2AFY & Chromosome organization and biogenesis \\
\hline 2 & 207305_s_at & 1 & AB023229 & KIAA1012 & Intracellular transporter activity \\
\hline 3 & 201136_at & $\backslash$ & L09604 & PLP2 & A4 differentiation-dependent protein \\
\hline 4 & 212055_at & $\backslash$ & ВC015178 & C18orf10 & Unknown, DKFZP586M1523 protein \\
\hline 5 & 213628_at & $\backslash$ & ВС002939 & MCLC & Unknown, Mid-1-related chloride channel 1 \\
\hline 6 & 214988_s_at & $\backslash$ & AF380179 & $\mathrm{SON}$ & Anti-apoptosis \\
\hline 7 & 203075_at & $\backslash$ & ВC014840 & MADH2 & Regulation of transcription, DNA-dependent \\
\hline 8 & 214351_x_at & / & AA789278 & & Unknown \\
\hline 9 & 203255_at & $\backslash$ & AF351618 & FBXO11 & Ubiquitin conjugating enzyme activity \\
\hline 10 & 205191_at & $\backslash$ & AJ007590 & RP2 & ß-tubulin folding \\
\hline 11 & 221482_s_at & $\backslash$ & P56211 & ARPP-19 & Positive regulation of glucose import \\
\hline 12 & 218134_s_at & $\backslash$ & AK001152 & FLJ10290 & Nucleic acid binding \\
\hline 13 & 201345_s_at & $\backslash$ & U39317 & UBE2D2 & Invasive growth \\
\hline 14 & 210844_x_at & $\backslash$ & L23805 & CTNNA1 & Cell adhesion molecule activity \\
\hline 15 & 219762_s_at & / & AF077043 & RPL36 & Structural constituent of ribosome \\
\hline 16 & 211069_s_at & $\backslash$ & U83117 & UBL1 & Ubiquitin conjugating enzyme activity \\
\hline 17 & 213134_x_at & $\backslash$ & D64110 & BTG3 & Negative regulation of cell proliferation \\
\hline 18 & 208929_x_at & / & X64707 & RPL13 & Structural constituent of ribosome \\
\hline 19 & 205324_s_at & $\backslash$ & AF063015 & FTSJ1 & Cell division protein \\
\hline 20 & 221193_s_at & $\backslash$ & AK000101 & $\mathrm{ZCCHC} 10$ & Unknown, nucleic acid binding \\
\hline 21 & 212191_x_at & / & AW574664 & & Unknown \\
\hline 22 & 217982_s_at & $\backslash$ & AF100615 & MORF4L1 & Regulation of cell growth \\
\hline 23 & 202163_s_at & 1 & AL122045 & CNOT8 & Regulation of transcription, DNA-dependent \\
\hline 24 & 208642_s_at & $\backslash$ & J04977 & XRCC5 & Unknown, DNA recombination \\
\hline 25 & 202502_at & 1 & M16827 & ACADM & Fatty acid metabolism \\
\hline 26 & 212591_at & $\backslash$ & AB030181 & ARID4B & Retinoblastoma-binding protein 1-like 1 \\
\hline 27 & 202334_s_at & $\backslash$ & M74525 & UBE2B & Ubiquitin conjugating enzyme activity \\
\hline 28 & 215963_x_at & / & Z98200 & & Unknown \\
\hline 29 & 208839_s_at & $\backslash$ & AL136810 & TIP120A & TIP120 protein \\
\hline 30 & 40446_at & $\backslash$ & O43189 & PHF1 & Regulation of transcription, DNA-dependent \\
\hline 31 & 219489_s_at & $\backslash$ & AL139260 & RHBDL2 & Serine-type endopeptidase activity \\
\hline 32 & 209224_s_at & $\backslash$ & ВC003674 & NDUFA2 & NADH dehydrogenase (ubiquinone) activity \\
\hline 33 & 202557_at & $\backslash$ & AI718418 & & Unknown, Stress 70 protein chaperone \\
\hline 34 & 206272_at & $\backslash$ & X82554 & SPHAR & DNA replication \\
\hline 35 & 219454_at & $\backslash$ & AF186084 & EGFL6 & Cell cycle, oncogenesis \\
\hline 36 & 209090_s_at & 1 & AF263293 & RPL17 & Unknown, endophilin B1 \\
\hline 37 & 201390_s_at & $\backslash$ & X57152 & CSNK2B & Protein kinase $\mathrm{CK} 2$, intrinsic regulator \\
\hline 38 & 218738_s_at & 1 & AF162680 & STRIN & Ring finger protein 138 \\
\hline 39 & 205335_s_at & $\backslash$ & X12791 & SRP19 & Signal recognition particle \\
\hline 40 & 212372_at & $\backslash$ & AK026977 & MYH10 & Cytokinesis \\
\hline 41 & 201546_at & $\backslash$ & D28476 & TRIP12 & Thyroid receptor interacting protein 12 \\
\hline 42 & 218350_s_at & $\backslash$ & AF067855 & & Cell cycle arrest \\
\hline 43 & 201441_at & $\backslash$ & BC001015 & COX6B & Cytochrome c oxidase activity \\
\hline 44 & 209787_s_at & $\backslash$ & BC001282 & HMGN4 & High mobility group protein N4 \\
\hline 45 & 203689_s_at & $\backslash$ & AI743037 & & Unknown, fragile $\mathrm{X}$ mental retardation 1 \\
\hline 46 & 213857_s_at & $\backslash$ & BG230614 & & Unknown \\
\hline 47 & 215245_x_at & $\backslash$ & AA830884 & & Unknown, nucleoplasm \\
\hline 48 & 203077_s_at & $\backslash$ & U59911 & MADH2 & Regulation of transcription, DNA-dependent \\
\hline
\end{tabular}

/, up-regulated genes in pT1 tumors with lymph node metastasis; \, down-regulated genes in pT1 tumors with lymph node metastasis. 
Supplementary Table III. Top 66 genes whose expression levels differed between pT1 tumors without lymph node metastasis and pT2-4 tumors without lymph node metastasis.

\begin{tabular}{|c|c|c|c|c|c|}
\hline Order & & & Gene Accession no. & Symbol & Function \\
\hline 1 & 201371_s_at & $\backslash$ & Q13618 & CUL3 & Induction of apoptosis by intracellular signals \\
\hline 2 & 212365_at & / & G09498 & MYO1B & Unknown, myosin-I $\alpha$ \\
\hline 3 & 200929_at & / & U61734 & TMP21 & Intracellular protein transport \\
\hline 4 & 218353_at & $\backslash$ & AA486366 & RGS5 & Peripheral plasma membrane protein \\
\hline 5 & 40446_at & $\backslash$ & AL021366 & PHF1 & Regulation of transcription, DNA-dependent \\
\hline 6 & 218034_at & / & AF151893 & TTC11 & Tetratricopeptide repeat domain 11 \\
\hline 7 & 208967_s_at & / & U84371 & AK2 & Adenylate kinase, mitochondrial \\
\hline 8 & 203255_at & $\backslash$ & AF351618 & FBXO11 & Ubiquitin conjugating enzyme activity \\
\hline 9 & 202502_at & $\backslash$ & M16827 & ACADM & Fatty acid $\beta$-oxidation \\
\hline 10 & 201245_s_at & / & AK000120 & OTUB1 & Ubiquitin-specific protease otubain 1 \\
\hline 11 & 217294_s_at & / & M14328 & ENO1 & Negative regulation of transcription \\
\hline 12 & 203675_at & $\backslash$ & X76732 & NUCB2 & Nucleobindin 2 \\
\hline 13 & 200634_at & / & ВC002475 & PFN1 & Cytoskeleton organization and biogenesis \\
\hline 14 & 218320_s_at & $\backslash$ & AF251063 & P17.3 & Neuronal protein 17.3 \\
\hline 15 & 209126_x_at & / & L42584 & KRT6B & Structural constituent of cytoskeleton \\
\hline 16 & 201348_at & $\backslash$ & D16360 & GPX3 & Glutathione peroxidase activity \\
\hline 17 & 211727_s_at & $\backslash$ & AF044321 & COX11 & Cytochrome $\mathrm{c}$ oxidase biogenesis \\
\hline 18 & 202299_s_at & $\backslash$ & AA443738 & HBXIP & Viral replication, invasive growth \\
\hline 19 & 208308_s_at & / & K03515 & GPI & Humoral immune response, cytokine activity \\
\hline 20 & 200849_s_at & $\backslash$ & AF315687 & AHCYL1 & Dendritic cell expressed AHCY-like protein \\
\hline 21 & 211698_at & $\backslash$ & AF092135 & CRI1 & Chromosome 15 open reading frame 3 \\
\hline 22 & 201014_s_at & / & ВC010273 & PAICS & Purine nucleotide biosynthesis \\
\hline 23 & 204446_s_at & $\backslash$ & J03600 & ALOX5 & Lipoxygenase activity \\
\hline 24 & 200823_x_at & / & ВC008926 & RPL29 & Structural protein of ribosome \\
\hline 25 & 200641_s_at & / & M86400 & YWHAZ & Protein domain specific binding \\
\hline 26 & 202605_at & $\backslash$ & M15182 & GUSB & Glycosaminoglycan catabolism \\
\hline 27 & 218683_at & $\backslash$ & AF176085 & PTBP2 & Neural polypyrimidine tract binding protein \\
\hline 28 & 208921_s_at & / & AL117616 & SRI & Calcium channel regulator \\
\hline 29 & 208627_s_at & / & ВC010430 & NSEP1 & Major histocompatibility complex, class II \\
\hline 30 & 218518_at & $\backslash$ & AF251038 & C5orf5 & Unknown, chromosome 5 open reading frame 5 \\
\hline 31 & 212195_at & $\backslash$ & AL049265 & & Unknown \\
\hline 32 & 202850_at & $\backslash$ & M81182 & ABCD3 & ATP-binding cassette \\
\hline 33 & 213969_x_at & / & BF683426 & & Unknown \\
\hline 34 & 200703_at & / & U32944 & PIN & Microtubule motor activity \\
\hline 35 & 202797_at & 1 & AB020658 & KIAA0851 & Suppressor of actin 1 \\
\hline 36 & 203053_at & $\backslash$ & AF081788 & BCAS2 & Pre-mRNA splicing factor activity \\
\hline 37 & 213251_at & $\backslash$ & AV712064 & SWISNF & Chromatin modeling \\
\hline 38 & 201259_s_at & / & Q16563 & SYPL & Pantophysin \\
\hline 39 & 214988_s_at & 1 & X63071 & DBP-5 & Apoptosis inhibitor activity \\
\hline 40 & 201841_s_at & / & U90906 & HSPB 1 & Heat shock protein activity \\
\hline 41 & 201897_s_at & / & ВC001425 & CKS1 & Cytokinesis \\
\hline 42 & 222294_s_at & $\backslash$ & AW971415 & & Unknown \\
\hline 43 & 217772_s_at & / & BC000875 & MTCH2 & Mitochondrial carrier homolog 2 \\
\hline 44 & 203455_s_at & $\backslash$ & M77693 & SAT & Diamine $\mathrm{N}$-acetyltransferase activity \\
\hline 45 & 202429_s_at & $\backslash$ & L14778 & DKFZp761L0516 & Protein phosphatase- 3 \\
\hline 46 & 205401_at & / & Y09443 & AGPS & Alkylglycerone-phosphate synthase activity \\
\hline 47 & 208767_s_at & / & AW149681 & & Putative integral membrane transporter \\
\hline 48 & 209363_s_at & / & U46837 & SRB7 & Regulation of transcription from PolII promoter \\
\hline 49 & 217975_at & $\backslash$ & AF125535 & LOC51186 & pp21 homolog \\
\hline 50 & 207168_s_at & $\backslash$ & AF054174 & H2AFY & Chromosome organization and biogenesis \\
\hline 51 & 201408_at & $\backslash$ & W67887 & & Unknown, protein phosphatase 1 \\
\hline 52 & 208675_s_at & / & D29643 & KIAA0115 & Glycosyltransferase \\
\hline 53 & 209022_at & $\backslash$ & ВC001765 & ARS & Unknown, cell cycle \\
\hline
\end{tabular}


Supplementary Table III. Continued.

\begin{tabular}{llllll}
\hline Order & & & Gene Accession no. & Symbol & \\
\hline 54 & 201892_s_at & $/$ & J04208 & IMPDH2 & Purine nucleotide biosynthesis \\
55 & 201063_at & $\backslash$ & D42073 & RCN1 & Endoplasmic reticulum lumen \\
56 & 202961_s_at & $/$ & AF047436 & ATP5J2 & Hydrogen ion transporter \\
57 & 209112_at & $\backslash$ & U10906 & Kip1 & TGF3 receptor, cytoplasmic mediator activity \\
58 & 212287_at & $\backslash$ & BF382924 & & Unknown, joined to JAZF1 \\
59 & 201231_s_at & $/$ & M14328 & ENO1 & Transcription co-repressor \\
60 & 203310_at & $\backslash$ & D63506 & STXBP3 & Intracellular protein transport \\
61 & 210338_s_at & $/$ & AB034951 & HSC54 & Heat shock protein activity \\
62 & 202371_at & $\backslash$ & AF271783 & FLJ21174 & Unknown, hypothetical protein FLJ21174 \\
63 & 202362_at & $\backslash$ & M22995 & RAP1A & Small GTPase mediated signal transduction \\
64 & 218622_at & $/$ & BC000861 & MGC5585 & Protein transporter activity \\
65 & 213347_x_at & $\backslash$ & AW132023 & & Unknown \\
66 & 215245_x_at & $\backslash$ & AA830884 & & Fragile X mental retardation 1 \\
\hline
\end{tabular}

/, up-regulated genes in pT2-4 tumors without lymph node metastasis; \, down-regulated genes in pT2-4 tumors without lymph node metastasis.

Supplementary Table IV. Top 30 genes whose expression levels differed between pT2-4 tumors without lymph node metastasis and pT2-4 tumors with lymph node metastasis.

\begin{tabular}{|c|c|c|c|c|c|}
\hline Order & & & Gene Accession no. & Symbol & Function \\
\hline 1 & 212820_at & / & AF389880 & $\mathrm{RC} 3$ & Rabconnectin-3 \\
\hline 2 & 212854_x_at & l & BC034418 & FLJ20719 & Unknown, hypothetical protein FLJ20719 \\
\hline 3 & 221027_s_at & 1 & BC017218 & PLA2G12A & Lipid catabolism \\
\hline 4 & 201534_s_at & / & BC059385 & UBL3 & Ubiquitin-like 3 \\
\hline 5 & 202443_x_at & / & X80115 & NOTCH2 & Notch 2 preproprotein \\
\hline 6 & 212365_at & 1 & BF215996 & MYO1B & Myosin-I $\alpha$ \\
\hline 7 & 208967_s_at & 1 & U84371 & $\mathrm{AK} 2$ & Adenylate kinase activity \\
\hline 8 & 218236_s_at & / & O94806 & PRKCN & Protein amino acid phosphorylation \\
\hline 9 & 213476_x_at & 1 & L26318 & MAPK8 & Microtubule-based movement \\
\hline 10 & 201757_at & 1 & AF047434 & NDUFS5 & Mitochondrial electron transport \\
\hline 11 & 214722_at & / & AW516297 & FLJ11946 & Unknown \\
\hline 12 & 200634_at & 1 & $\mathrm{BC} 002475$ & PFN1 & Cytoskeleton organization and biogenesis \\
\hline 13 & 201841_s_at & 1 & U90906 & HSPB1 & Heat shock protein \\
\hline 14 & 202605_at & l & M15182 & GUSB & ß-glucuronidase activity \\
\hline 15 & 201103_x_at & / & AF047442 & SEC22L1 & Unknown, hypothetical protein DJ328E19.C1.1 \\
\hline 16 & 215000_s_at & / & AF113124 & FEZ2 & Fasciculation and elongation protein $\zeta 2$ \\
\hline 17 & 212377_s_at & / & U77493 & NOTCH2 & Unknown, notch 2 preproprotein \\
\hline 18 & 218067_s_at & I & AK001016 & FLJ10154 & Unknown, hypothetical protein FLJ10154 \\
\hline 19 & 201322_at & 1 & M27132 & ATP5B & ATP synthesis coupled proton transport \\
\hline 20 & 210512_s_at & / & M63978 & VEGF & Vascular endothelial growth factor receptor binding \\
\hline 21 & 201725_at & 1 & D14878 & C10orf7 & Positive regulation of cell proliferation \\
\hline 22 & 218330_s_at & / & G28996 & FLJ20719 & Role in colorectal carcinogenesis \\
\hline 23 & 213374_x_at & 1 & U66669 & $\mathrm{HIBCH}$ & Unknown, 3-hydroxyisobutyryl-CoA hydrolase activity \\
\hline 24 & 220232_at & / & AK024685 & SCD4 & Stearoyl-CoA desaturase 4 \\
\hline 25 & 218249_at & / & AK025605 & ZDHHC6 & DHHC domain containing 6 , integral to membrane \\
\hline 26 & 219002_at & 1 & AK074302 & FLJ21901 & Unknown, hypothetical protein FLJ21901 \\
\hline 27 & 212043_at & l & W72053 & FLJ21904 & Unknown \\
\hline 28 & 209026_x_at & 1 & $\mathrm{P} 05218$ & OK/SW-cl.56 & Natural killer cell mediated cytolysis \\
\hline 29 & 202375_at & / & AB018298 & SEC24D & Protein transport protein Sec24D \\
\hline 30 & 211519_s_at & 1 & U63743 & $\mathrm{KIF} 2 \mathrm{C}$ & Microtubule motor activity \\
\hline
\end{tabular}

/, up-regulated genes in pT2-4 tumors with lymph node metastasis; \, down-regulated genes in pT2-4 tumors with lymph node metastasis. 